\title{
PENGUKURAN TINGKAT KEPUASAN MASYARAKAT TERHADAP PELAKSANAAN KEBIJAKAN PELAYANAN PEMERINTAH
}

\author{
MEASUREMENT OF SATISFACTION SOCIETY \\ POLICY IMPLEMENTATION OF GOVERNMENT SERVICES
}

\author{
Heri Wahyudianto B.P \\ Badan Perencanaan Pembangunan Daerah Provinsi Papua \\ Jl. Soa Siu Dok II Jayapura. Telepon. (0967) 535334. \\ E-mail:w.wahyudianto@yahoo.com
}

Dikirim: 11 Juni 2015 Direvisi: 5 Juli 2015 Disetujui: 20 Oktober 2015

\begin{abstract}
Abstrak
Masalah pelayanan pemerintah yang dilakukan oleh aparatur pemerintah saat ini belum memenuhi harapan masyarakat. Hal ini dapat diketahui dari berbagai keluhan masyarakat yang disampaikan melalui media masa dan jaringan sosial, sehingga dapat memberikan dampak buruk terhadap kewibawaan pemerintah, yang menimbulkan ketidakpercayaan masyarakat. Tujuan tulisan ini adalah membahas konsep dan pemikiran yang berkaitan dengan kepuasan masyarakat, pelayanan publik, dan cara pengukurannya yang komprehensif. Hal yang paling penting dilakukan adalah survei kepuasan masyarakat terhadap penyelenggaraan pelayanan publik secara berkelanjutan sebagai dasar kemungkinan replikasi inovasi pelayanan publik. Perbaikan pelayanan publik yang paling mendasar adalah perbaikan sistem rekrutmen aparatur pelayan publik.
\end{abstract}

Kata Kunci: Kepuasan Masyarakat, Pelayanan, Aparatur Pemerintah.

\section{Abstract}

Problems government service conducted by government officials at this time have not met the expectations of society. It can be seen from the public complaints submitted through the mass media and social networks, so as to adversely affect government authority, which give rise to public mistrust. The purpose of this paper is to discuss the concepts and ideas related to the satisfaction of the public, public service, and a comprehensive measurement method. The most important thing to do is to survey people's satisfaction with the implementation of public services in a sustainable manner as a basis for public service innovation possible replication. Improvement of public services is the most basic repairs apparatus public servant recruitment system.

Keywords: Community Satisfaction, Service, Government Apparatus.

\section{PENDAHULUAN}

Kegiatan pelayanan publik oleh aparatur pemerintah (termasuk aparatur pemerintah kelurahan) dalam pelaksanaan pemerintahan adalah sesuatu yang tak terhindarkan, suatu keharusan, di mana masyarakat mengharapkan hadirnya pemerintahan di semua tingkatan yang lebih tinggi kualitasnya, lebih mampu mengemban fungsi-fungsi pelayanan publik, pemberdayaan masyarakat, dan pembangunan sosial ekonomi (Ryaas, 2009: 12). Melalui optimalisasi atas fungsi-fungsi pemerintahan ini (terutama pelaksanaan fungsi-fungsi pelayanan publik), masyarakat bisa berharap semakin luasnya rasa keadilan, semakin tingginya tingkat kemandirian mereka dalam mengembangkan diri dan menyelesaikan berbagai masalah, serta semakin membaiknya tingkat kesejahteraan mereka. Jika harapan tersebut terwujud, maka masyarakat akan puas atas pelayanan yang diberikan oleh aparatur pemerintah sebagai public servant (pelayan masyarakat).
Tidak dapat dihindari bahwa model birokrasi yang kita perlu jalankan di era modernisasi adalah model Public Service Orientation atau birokrasi yang berorientasi kepada pelayanan publik (Samodra dan Yuyun, 2008: 46). Pelayanan publik adalah berbagai kegiatan yang bertujuan memenuhi kebutuhan masyarakat akan barang-barang dan jasa-jasa (Pamudji, 2004: 17). Adapun pelayanan publik oleh aparatur pemerintahan kelurahan adalah berkaitan dengan pelayanan masyarakat setempat, seperti pelayanan KTP, Kartu Keluarga (KK), perijinan tertentu, dan sebagainya. Berbagai pelayanan publik tersebut harus dijalankan secara profesional sehingga menghasilkan pelayanan publik yang lebih baik mutu/kualitasnya, lebih cepat prosesnya, dan mungkin lebih bervariasi, yang kesemuanya mendatangkan kepuasan pada warga masyarakat yang dilayani. Dalam konteks ini, warga masyarakat diposisikan sebagai konsumen.

Pelayanan publik (public service) oleh aparatur pemerintah dewasa ini masih banyak dijumpai kelemahan sehingga belum dapat 
memenuhi kualitas yang diharapkan masyarakat. Hal ini ditandai dengan masih adanya berbagai keluhan masyarakat yang disampaikan melalui media massa, sehingga dapat menimbulkan citra yang kurang baik terhadap aparatur pemerintah (Ratminto dan Winarsih, 2005: 165). Mengingat fungsi utama pemerintahan adalah melayani masyarakat, maka pemerintah perlu terus berupaya meningkatkan kualitas pelayanannya agar masyarakat menjadi lebih puas di dalam menerima pelayanan dari pemerintah.

Kepuasan masyarakat atas pelayanan aparatur pemerintah merupakan salah satu isu yang sangat krusial dalam pelaksanaan pelayanan publik (public service). Menurut Daha (2000: 76), hal ini terjadi karena di satu sisi tuntutan kepuasan masyarakat atas pelayanan pemerintah menjadi besar, sedangkan dalam praktik pelaksanaannya pelayanan yang diberikan oleh aparatur pemerintah kurang mengalami perbaikan kinerja yang berarti (sigifikan). Di samping itu, seiring dengan besarnya tuntutan akan penerapan good governace (pemerintahan yang baik), tuntutan akan pelayanan publik yang berkualitas dan yang dapat memuaskan masyarakat yang dilayani juga semakin besar. Oleh karena itu, adalah merupakan keharusan bagi aparatur pemerintah sebagai sosok public servant (pelayan masyarakat) untuk senantiasa berupaya memuaskan warga masyarakat yang di layaninya.

Pemerintah telah merespon tuntutan pentingnya kepuasan masyarakat dicapai dalam setiap pelayanan publik tersebut di atas dengan menetapkan tahun 2004 sebagai tahun peningkatan pelayanan publik. Pemerintah juga telah mengeluarkan berbagai kebijakan dalam rangka peningkatan pelayanan publik dan pemenuhan kepuasan masyarakat, seperti pelayanan prima, Standar Pelayanan Minimal (SPM), dan Pedoman Umum Penyusunan Indeks Kepuasan Masyarakat Unit Pelayanan Instansi Pemerintah (berdasarkan Kep. Menpan No. KEP/25/M.PAN/2/2004 Tanggal 24 Pebruari 2004). Di dalam Kep. Menpan No. 63 Tahun 2004 tentang Pedoman Penyelenggaraan Pelayanan, diamanatkan agar setiap penyelenggara pelayanan secara berkala melakukan survai Indeks Kepuasan Masyarakat.

Kedua keputusan di atas adalah dalam rangka menilai tingkat kualitas pelayanan aparatur pemerintah yang dilakukan oleh setiap instansi pemerintah. Data indeks kepuasan masyarakat akan dapat menjadi bahan penilaian terhadap unsur pelayanan yang masih perlu diperbaiki dan menjadi pendorong setiap unit penyelenggara pelayanan untuk meningkatkan kualitas pelayanannya.

Akan tetapi, faktanya hingga saat ini masyarakat masih merasakan kualitas pelayanan aparatur pemerintah yang jauh dari apa yang diharapkan, dan masyarakat merasa belum puas atas pelayanan yang diberikan oleh aparat pemerintah. Dalam banyak kasus, pelayanan yang diberikan oleh aparatur pemerintah masih kurang efesien dan efektif, masih lamban, kurang sesuai kebutuhan masyarakat, berbelit-belit, dan sebagainya (Kedaulatan Rakyat, 2013). Selain itu, walaupun aparatur pemerintah telah dibekali dengan peraturan (aturan main) dan prosedur pelayanan yang jelas, namun dalam praktiknya yang terjadi adalah justru prosedur pelayanannya tidak jelas dan kadangkadang tidak transparan.

Kelemahan yang lain dari aparatur pemerintah adalah, kecenderungannya untuk menghasilkan gap (ketimpangan) pelayanan (service) dan kekuasaan (power) dan memberi privileges (hak istimewa) kepada kelompok tertentu dalam masyarakat (Agus, 2006: 29). Banyak kasus menunjukkan bias kebijakan birokrasi yang memihak kepada elit politik dan ekonomi, dan merugikan kepentingan masyarakat banyak. Praktik kolusi seringkali terjadi antara birokrasi dengan pengusaha dan pemegang kekuasaan politik. Pemberian kekuasaan monopoli dan fasilitas-fasilitas khusus lainnya kepada sekelompok pengusaha tertentu bisa menjadi contoh dari privileges (hak istimewa) ini. Berbagai kondisi di atas menyebabkan masyarakat masih kurang puas atas layanan yang diberikan oleh aparatur pemerintah hingga saat ini.

Disamping itu, kondisi sesungguhnya birokrasi Indonesia saat ini dapat digambarkan bahwa secara generik, ukuran keberhasilan birokrasi sendiri sudah tidak sesuai dengan tuntutan organisasional yang baru. Di Indonesia, birokrasi di kementerian atau pemerintahan paling rendah, yang diutamakan adalah masukan dan proses, bukan hasil. Karenanya, yang selalu diperhatikan oleh para pelaku birokrasi adalah jangan sampai ada sisa pada akhir tahun buku. Birokrasi kita tidak pernah menyadari bahwa ada perubahan besar di dunia, di mana semua hal harus mengacu kepada pasar, bisnis harus mengacu kepada permintaan pasar, dan kalau mau berhasil dalam kompetisi ia harus mampu melayani pasar. Pasar birokrasi adalah seluruh masyarakat, yang dilayani oleh birokrasi bukannya pejabat pemerintahan atau pimpinan birokrasi itu sendiri, tetapi rakyat.

Tingginya tingkat penyalahgunaan kewenangan dalam bentuk KKN. Upaya pemberantasan KKN merupakan salah satu tuntutan penting pada awal reformasi. Namun prevalensi KKN semakin meningkat dan menjadi permasalahan di seluruh lini pemerintahan dari pusat hingga daerah. Tuntutan akan peningkatan profesionalisme sumber daya manusia aparatur negara yang berdaya guna, produktif dan bebas KKN serta sistem yang transparan, akuntabel dan partisipatif masih memerlukan solusi tersendiri. Ini berkaitan dengan semakin buruknya citra dan kinerja birokrasi dan rendahnya kepercayaan masyarakat terhadap penyelenggaraan pemerintahan. KKN telah menjadi extraordinary state of affairs di Indonesia Laporan terakhir di penghujung tahun 2003 mengukuhkan Indonesia di urutan ke-6 negara terkorup didunia. 
Berdasarkan hasil survei Transparency International (TI) dari 133 negara, Indonesia berada diurutan ke 122 dari 133 negara terkorup.

Permasalahan yang pokok lainnya adalah sistem pelayanan publik yang belum diatur secara jelas dan tegas. Unsur terpenting dari sebuah sistem pelayanan publik yang belum diatur secara lebih jelas dan tegas di dalam sistem pelayanan publik di Indonesia dewasa ini adalah Kode Perilaku Petugas Pelaksana Pelayanan Publik (Code of Conduct for Public Servants). Hal ini menjadi salah satu faktor penentu keberhasilan sistem pelayanan publik, terutama bila disadari bahwa sebagian besar dari permasalahan dan keluhan mengenai pelayanan publik di Indonesia dapat dikembalikan pada unsur manusia pengemban fungsi pelayanan publiknya (ekses-ekses KKN, conflict of interest, dsb.). Kehadiran sebuah Code of Conduct yang selengkapnya mungkin akan lebih mengkokohkan struktur dasar dari Sistem Pelayanan Publik Indonesia.

\section{METODE}

Terkait dengan permasalahan pelayanan pemerintah di atas, maka rumusan masalah tulisan ini adalah bagaimana konsep dan pemikiran yang berkaitan dengan kepuasan masyarakat, pelayanan pemerintah, serta cara pengukuran yang tepat dan komprehensif mengenai tingkat kepuasan masyarakat atas pelaksanaan kebijakan pelayanan pemerintah? Pembahasan ini dapat berguna bagi aparat pemberi pelayanan publik dalam mengetahui tingkat kepuasan masyarakat yang dilayani.

\section{HASIL DAN PEMBAHASAN}

\section{Pengertian Kepuasan Masyarakat Dan Pelayanan Pemerintah}

Secara konseptual, kepuasan berasal dari kata puas yang berarti perasaan senang (Handoko, 2005: 88), sedangkan masyarakat diartikan sebagai komunitas, kumpulan orang-orang, rakyat banyak (Dahlan, 2004: 132). Adapun kepuasan masyarakat (dalam konteks kepuasan pelayanan) diartikan sebagai hasil pendapat dan penilaian masyarakat terhadap kinerja pelayanan yang diberikan oleh aparatur penyelenggara pelayanan publik (Ratminto dan Winarsih, 2005: 90), yang tercermin dari rasa senang/puas masyarakat atas pelayanan yang diberikan oleh aparatur pemerintah.

Kepuasan itu sendiri menurut Kotler (2004: 198) adalah perasaan senang atau kecewa seseorang yang muncul setelah membandingkan antara persepsi/kesannya terhadap kinerja (atau hasil) suatu produk dan harapan-harapan. Kepuasan masyarakat merupakan faktor yang sangat penting dan menentukan keberhasilan suatu badan usaha karena masyarakat adalah konsumen dari produk yang dihasilkannya. Hal ini didukung oleh pernyataan
Hoffman dan Beteson (2007: 34), yaitu: "weithout customers, the service firm has no reason to exist." Definisi kepuasan masyarakat menurut Mowen (2005: 180) adalah: "Customers satisfaction is defined as the overall attitudes regarding goods or services after its acquisition and uses." Oleh karena itu, badan usaha harus dapat memenuhi kebutuhan dan keinginan masyarakat sehingga mencapai kepuasan masyarakat dan lebih jauh lagi kedepannya dapat dicapai kesetiaan masyarakat. Sebab, bila tidak dapat memenuhi kebutuhan dan kepuasan masyarakat sehingga menyebabkan ketidakpuasan masyarakat mengakibatkan kesetiaan masyarakat akan suatu produk menjadi luntur dan beralih ke produk atau layanan yang disediakan oleh badan usaha yang lain.

Menurut Mendelsohn (2008; 66) ada 2 keuntungan bagi badan usaha dengan adanya kepuasan masyarakat, yaitu: "First, retaining customers is less expensive than acquiring new ones. Second, increasing competition in the form of product, organizations, and distributing outlets means fierce pressure for costumers. And costumners satisfaction is viable strategy to maintain market share against the competitions." Untuk mengukur kepuasan masyarakat digunakan atribut yang berisi tentang bagaimana masyarakat menilai suatu produk atau layanan yang ditinjau dari sudut pandang pelanggan.

Menurut Mote (2008: 92), kepuasan masyarakat dapat diukur melalui atribut-atribut pembentuk kepuasan yang terdiri atas: Value to price relationship, yaitu hubungan antara harga yang ditetapkan oleh badan usaha untuk dibayar dengan nilai/manfaat yang diperoleh masyarakat; Product value, yaitu penilaian dari kualitas produk atau layanan yang dihasilkan suatu badan usaha; Product benefit; yaitu manfaat yang diperoleh masyarakat dari mengkosumsi produk yang dihasilkan oleh badan usaha; Product feature, yaitu ciri-ciri atau karakteristik tertentu yang mendukung fungsi dasar dari suatu produk sehingga berbeda dengan produk yang ditawarkan pesaing; Product design, yaitu proses untuk merancang tampilan dan fungsi produk; Product reliability and consistency; yaitu kekakuratan dan keandalan produk ang dihasilkan oleh suatu badan usaha; dan Range of product ar services, yaitu macam dari produk atau layanan yang ditawarkan oleh suatu badan usaha.

Kemudian attribute related to service meliputi (Mote, 20081): Guarantee or warranty, yaitu jaminan atau garansi yang diberikan oleh badan usaha dan diharapkan dapat memuaskan masyarakat; Delivery communication, yaitu pesan atau informasi yang disampaikan oleh badan usaha kepada masyarakatnya; Complain handling, yaitu adalah sikap badan usaha dalam menangani keluhankeluhan atau pengaduan; dan Resolution of problem, yaitu tanggapan yang diberkan badan usaha 
dalam membantu memecahkan masalah masyarakat yang berkaitan dengan layanan yang diterimanya.

Selanjutnya attributes related to the purchase meliputi (Mote, 2008; 11): Courtesy, yaitu kesopanan, perhatian dan keramahan pegawai; Communication, yaitu kemampuan pegawai dalam melakukan komunikasi dengan masyarakat pelanggan; Ease or convinience of acquisition, yaitu kemudahan yang diberikan oleh badan usaha untuk mendapatkan produk atau layanan yang ditawarkan; Company reputation, yaitu baik tidaknya reputasi yang dimiliki oleh badan usaha dalam melayani masyarakat; dan Company competence, yaitu baik tidaknya kemampuan badan usaha dalam melayani masyarakat.

Adapun pelayanan (dalam konteks pelayanan publik oleh pemerintah) adalah segala kegiatan pelayanan yang dilaksanakan oleh penyelenggara pelayanan publik sebagai upaya pemenuhan kebutuhan penerima pelayanan (dalam hal ini warga masyarakat), maupun dalam rangka pelaksanaan peraturan perundang-undangan (Ratminto dan Winarsih, 2005: 201).

Berdasarkan konsep di atas, secara umum dapat dikatakan bahwa kepuasan masyarakat atas pelayanan publik oleh pemerintah adalah perasaan senang/puas atau tidak senang/tidak puas warga masyarakat atas segala kegiatan pelayanan yang dilakukan oleh pemerintah dan perangkatnya sebagai upaya pemenuhan kebutuhan warga masyarakat yang di layaninya.

Selanjutnya, konsep lain dari pelayanan publik dapat dicermati dari berbagai pandangan pakar pemerintahan dan manajemen pelayanan. Menurut Taliziduhu (2000: 52), layanan dapat diartikan sebagai produk dan dapat juga diartikan sebagai cara atau alat yang digunakan oleh provider (penyedia layanan) dalam memasarkan atau mendistribusikan produknya. Jika barang dan jasa dianggap sebagai produk (komoditi), maka perdagangannya dapat disertai dengan layanan sebagai cara atau alat. Layanan dalam pengertian itu adalah layanan sebagai produk.

Pengertian pelayanan publik dapat ditelusuri melalui istilah layanan civil. Istilah civil berasal dari kata Latin, civil (kata sifat), yaitu segala sesuatu yang menyangkut kehidupan sehari-hari warganegara di luiar urusan militer dan ibadah. Pelayanan civil semula diartikan sebagai suatu cabang pelayanan publik, menyangkut semua fungsi pemerintahan di luar pelayanan militer. Seiring dengan perkembangan masyarakat ilmu pengetahuan, setiap disiplin memakai konsep-konsep itu dalam konteks yang berbeda-beda, sehingga setiap pemakaian mempunyai konteks yang berbedabeda pula.

Layanan civil dapat dibedakan menjadi layanan civil guna memenuhi hak bawaan (asasi) manusia dan layanan civil guna memenuhi hak derivatif, hak berian, atau hak sebagai akibat hukum yang menyangkut diri seseorang. Misalnya, wajib minta ijin jika seseorang ingin membuka usaha.

Provider (penyedia) layanan civil yang disebut belakang di atas adalah birokrasi. Oleh karena itu, layanan civil jenis itu dapat juga disebut layanan birokrasi atau layanan publik. Jadi, layanan birokrasi atau layanan publik termasuk di dalam layanan civil. Mengingat produk birokrasi itu bersifat jasa, maka birokrasi adalah pabrik jasa pemerintahan. Dalam kaitan ini, Taliziduhu (2000: 59) menegaskan bahwa di Indonesia, pelayanan birokrasi atau pelayanan publik itu yang paling lemah dan terkesan sebagai sarang $\mathrm{KKN}$, dan lebih dari pada itu berperan sebagai pasar politik. Birokrasi memasang "jebakan" melalui peraturan, lalu menetapkan "tarif" yang tinggi, sementara warga masyarakat tidak mempunyai bargaining position (posisi tawar menawar) terhadap birokrasi.

Definisi yang sangat sederhana tentang pelayanan antara lain diberikan oleh Ivancevich, Lorenzi, Skinner, dan Crosby (2007: 111), yaitu pelayanan adalah produk-produk yang tidak kasat mata (tidak dapat diraba) yang melibatkan uisahausaha manusia dan menggunakan peralatan. Adapun menurut Gronroos (2000: 143), pelayanan adalah suatu aktivitas atau serangkaian aktivitas yang bersifat tidak kasat mata (tidak dapat diraba) yang terjadi sebagai akibat adanya interaksi antara konsumen dan karyawan atau hal-hal yang disediakan oleh organisasi pemberi pelayanan yang dimaksudkan untuk memecahkan permasalahan masyarakat yang dilayani.

Berdasarkan dua definisi di atas, maka dapat diketahui bahwa ciri pokok pelayanan adalah tidak kasat mata (tidak dapat diraba) dan melibatkan upaya manusia (karyawan) atau peralatan lain yang disediakan oleh organisasi penyelenggara pelayanan. Menurut Zemke, ciri lainnya untuk pelayanan jasa antara lain moral karyawan berperan sangat menentukan, serta tujuan pelaksanaan pelayanan adalah keunikan (setiap orang yang dilayani dan setiap kontak pelayanan adalah "spesial") (dalam Collins dan McLaughlin, 2006: 73).

Di Indonesia, konsep pelayanan administrasi pemerintahan seringkali dipergunakan secara bersama-sama atau dipakai sebagai sinonim dari konsep pelayanan perijinan, pelayanan umum, serta pelayanan publik. Keempat istilah pelayanan itu dipakai sebagai terjemahan dari public service. Hal ini dapat dilihat dalam dokumen-dokumen pemerintah sebagaimana dipakai oleh Kementerian Pendayagunaan Aparatur Negara.

Keputusan Menpan No. 81 Tahun 1993 tentang Pedoman Tatalaksana Pelayanan Umum, yang kemudian disempurnakan dengan Keputusan Menpan No. 63 Tahun 2003 tentang Pedoman Penyelenggaraan Pelayanan mendefinisikan pelayanan umum sebagai berikut: Segala bentuk pelayanan yang dilaksanakan instansi pemerintah di Pusat, di Daerah, dan di lingkungan BUMN atau 
BUMD dalam bentuk barang dan atau jasa, baik dalam rangka upaya pemenuhan kebutuhan masyarakat maupun dalam rangka pelaksanaan ketentuan peraturan perundang-undangan. Dalam pengertian ini, indeks kepuasan masyakat yang dilayani adalah tingkat kepuasan masyarakat dalam memperoleh pelayanan yang diperoleh dari penyelenggara atau pemberi pelayanan sesuai dengan harapan dan kebutuhan masyarakat.

Berdasarkan definisi di atas, maka pelayanan publik atau pelayanan umum dapat diartikan sebagai segala bentuk jasa pelayanan, baik dalam bentuk barang publik maupun jasa publik yang pada prinsipnya menjadi tanggung jawab dan dilaksanakan oleh instansi pemerintah di Pusat, di Daerah, dan di lingkungan BUMN atau BUMD dalam bentuk barang dan atau jasa, baik dalam rangka upaya pemenuhan kebutuhan masyarakat maupun dalam rangka pelaksanaan ketentuan peraturan perundang-undangan (Keputusan Menpan No. 63 Tahun 2003).

Adapun pelayanan administrasi pemerintahan atau pelayanan perijinan dapat diartikan sebagai segala bentuk jasa pelayanan yang pada prinsipnya menjadi tanggung jawab dan dilaksanakan oleh instansi pemerintah di Pusat, di Daerah, dan di lingkungan BUMN atau BUMD, baik dalam rangka upaya pemenuhan kebutuhan masyarakat maupun dalam rangka pelaksanaan ketentuan perundangundangan, yang bentuk produk layanannya adalah ijin atau waskat.

Pelayanan publik atau pelayanan umum dan pelayanan administrasi pemerintahan atau pelayanan perijinan tersebut mungkin dilakukan sebagai upaya pemenuhan kebutuhan masyarakat, misalnya upaya Kantor Pertanahan untuk memberikan jaminan kepastian hukum atau kepemilikan tanah dengan menerbitkan akta tanah, pelayanan penyediaan air bersih oleh PAM, pelayanan transportasi oleh Kemhub., pelayanan penyediaan listrik oleh PLN, pelayanan pemberian KTP oleh Kantor Kelurahan, dan lain-lain. Pelayanan publik atau pelayanan umum dan pelayanan administrasi pemerintahan atau pelayanan perijinan juga mungkin diselenggarakan sebagai pelaksanaan peraturan perundang-undangan. Misalnya, karena adanya ketentuan perundangundangan bahwa setiap orang yang melaksanakan pesta perkawinan harus memiliki ijin pesta keramaian dari Kantor Kelurahan dan Polsek setempat, maka diselenggarakan pelayanan perinjinan tersebut. Demikian halnya yang berkaitan dengan perlunya ada surat pengantar kelakuan baik, surat laporan kehilangan, surat pengantar UUG, dan lain-lain.

Kebijakan publik adalah keputusan-keputusan yang mengikat bagi orang banyak pada tataran strategis atau bersifat garis besar yang dibuat oleh pemegang otoritas publik. Sebagai keputusan yang mengikat publik maka kebijakan publik haruslah dibuat oleh otoritas politik, yakni mereka yang menerima mandat dari publik atau orang banyak, umumnya melalui suatu proses pemilihan untuk bertindak atas nama rakyat banyak. Selanjutnya, kebijakan publik akan dilaksanakan oleh administrasi negara yang dijalankan oleh birokrasi pemerintah. Fokus utama kebijakan publik dalam negara modern adalah pelayanan publik, yang merupakan segala bentuk jasa pelayanan, baik dalam bentuk barang maupun jasa publik yang pada prinsipnya menjadi tanggung jawab dan dilaksanakan oleh negara untuk mempertahankan atau meningkatkan kualitas kehidupan orang banyak.

\section{Prinsip-Prinsip Pelayanan Pemerintah}

Secara normatif yang dapat dijadikan pembanding acuan teoretik, prinsip-prinsip pelayanan publik/pemerintah didasarkan pada hakikat dan asas-asas pelayanan publik. Dalam Keputusan Menpan No. 63 Tahun 2003 dinyatakan bahwa hakikat pelayanan publik adalah pemberian pelayanan prima kepada masyarakatt yang merupakan perwujudan kewajiban aparatur pemerintah sebagai abdi masyarakat.

Berdasarkan Keputusan Menpan di atas, maka untuk dapat memberikan pelayanan yang memuaskan bagi pengguna jasa, penyelenggaraan pelayanan harus memenuhi asas-asas pelayanan, yaitu : transparan (bersifat terbuka, mudah dan dapat diakses oleh semua pihak yang membutuhkan dan disediakan secara memadai serta mudah dimengerti); akuntabilitas (dapat dipertanggung jawabkan sesuai dengan kebutuhan perundangan); kondisional (sesuai dengan kondisi dan kemampuan pemberi serta penerima pelayanan dengan tetap berpegang pada prinsip efesiensi dan efektivitas); partisipatif (mendorong peranserta masyarakat dalam pelaksanaan pelayanan publik dengan memperhatikan aspirasi, kebutuhan, dan harapan masyarakat); kesamaan hak (tidak diskriminatif, dalam arti tidak membedakan suku, ras, agama, golongan, gender, dan status ekonomi); dan keseimbangan hak dan kewajiban (pemberi dan penerima pelayanan publik harus memenuhi hak dan kewajiban masing-masing pihak).

Prinsip-prinsip pelayanan publik dilandasi oleh hakikat dan asas-asas tersebut di atas, yaitu: kesederhanaan (prosedur pelayanan tidak berbelitbelit, mudah dipahami, dan mudah dilaksanakan); kejelasan (misalnya kejelasan persyaratan teknis dan administrasi pelayanan publik); kepastian waktu (dapat dilaksanakan dalam kurun waktu yang telah ditentukan); akurasi (produk layanan publik diterima dengan benar, tepat, dan sah); keamanan (proses dan produk pelayanan publik memberikan rasa aman dan kepastian hukum); tanggung jawab (pimpinan penyelenggara pelayanan publik bertanggung jawab atas pelaksanaan pelayanan dan penyelesaian keluhan atau persoalan dalam pelaksanaan pelayanan publik); kelengkapan sarana dan prasarana (tersedianya sarana dan prasarana kerja, peralatan 
kerja, dan pendukung lainnya yang memadai, termasuk penyediaan sarana teknologi dan informatika atau telematika); kemudahan akses (termpat dan lokasi serta sarana pelayanan yang memadai, mudah dijangkau oleh masyarakat, dan dapat memanfaatkan telematika); kedisiplinan, kesopanan, dan keramahan (pemberian pelayanan harus bersikap disiplin, sopan santun, ramah, serta memberikan pelayanan yang ikhlas); dan kenyamanan (lingkungan pelayanan harus tertib, teratur, disediakan ruang tunggu yang nyaman, bersih, rapi, dan lingkungan yang indah, sehat, serta dilengkapi dengan fasilitas pendukung pelayanan seperti parkir, toilet, tempat ibadah, dan lain-lain).

\section{Karakteristik dan Bentuk-Bentuk Pelaksanaan Pelayanan Pemerintah}

Lembaga pelayanan publik/pemerintah atau pelayanan umum yang dilakukan oleh lembaga publik (instansi pemerintah) dapat bersifat primer dan dapat pula bersifat sekunder (Ratminto dan Winasih, 2005: 81). Lembaga yang bersifat primer adalah semua penyediaan barang atau jasa publik yang diselenggarakan oleh pemerintah yang di dalamnya pemerintah merupakan satu-satunya penyelenggara dan pengguna mau tidak mau harus memanfaatkannya. Misalnya, pelayanan di kantor imigrasi, pelayanan penjara, dan pelayanan perijinan. Adapun lembaga yang bersifat sekunder adalah segala bentuk penyediaan barang atau jasa publik yang diselnggarakan oleh pemerintah, tetapi di dalamnya pengguna tidak harus mempergunakannya karena adanya beberapa penyelenggara pelayanan, misalnya, program asuransi tenaga kerja, program pendidikan, dan pelayanan yang diberikan oleh BUMN.

Agus (2006: 69) mengidentifikasi beberapa ciri lembaga pelayanan publik oleh birokrasi pemerintah, yaitu: penilaian agak sulit, persyaratan informasi berdasarkan peraturan, tingkat kepercayaan cukup tinggi, dan persyaratan normatif bersifat kebutuhan timbal balik serta dikaitkan dengan penerimaan kewenangan.

Dalam konteks kemitraan pelayanan pemerintah-swasta (swastanisasi), pemerintah akan dengan mudah menilai apakah pelayanan dari pihak swasta telah melakukan tugasnya dengan baik, sesuai dengan kontrak atau tidak. Kalau penilaian pelayanan itu sulit dilakukan dan pelayanan itu dikontrakkan kepada swasta, maka akan sangat mungkin swasta itu akan menyalah gunakan kontraknya dan merugikan masyarakat banyak. Dalam kondisi semacam ini, sulit bagi pemerintah untuk memonitor seberapa besar swasta itu telah menjalankan kontraknya dengan benar.

Berdasarkan karakteristik di atas, maka pelayanan publik oleh birokrasi pemerintah bisa berjalan dengan baik kalu ada peraturan yang mengatur keberadaan dan prosedur pelayanannya. prosedur yang jelas dan transparan penting tidak hanya bagi birokrasi tetapi juga bagi masyarakat konsumen. Tanpa adanya aturan permainan yang jelas, maka birokrasi tidak akan dapat melayani secara efesien dan efektif. Pada sisi lain, aturan permainan yang jelas itu juga dapat melindungi masyarakat konsumen dari perilaku birokrasi yang sewenang-wenang.

Untuk pelayanan publik oleh birokrasi pemerintah, kepentingan timbal balik juga menuntut adanya penerimaan kewenangan. Birokrasi hanya bisa berjalan jika para anggota mengakui bahwa organisasi dan pimpinan memiliki kewenangan tertentu atas mereka. Adanya penerimaan kewenangan itu memungkinkan birokrasi menggerakkan para anggotanya melakukan sesuatu untuk mencapai tujuan organisasi dan pelayanan.

Kemudian, menurut Wolf, kelemahan utama birokrasi pemerintah dalam melakukan pelayanan publik adalah sering menjadi sumber inefesiensi, yaitu tidak adanya kaitan antara biaya layanan dan pendapatan (dalam Agus, 2006: 23). Anggaran birokrasi sering tidak berkaitan sama sekali dengan kemampuan mereka menekan biaya layanan. Bahkan, anggaran suatu birokrasi kadang-kadang lebih ditentukan oleh kemampuan lobi dan besarnya pengaruh pimpinannya. Suatu birokrasi bisa saja tetap survive dalam melayani masyarakat dan juga berkembang, kendati menghabiskan biaya yang banyak, kalau pemerintah melihat keberadaan birokrasi itu tetap penting dan pimpinannya memiliki akses yang besar tehadap sumber dana.

Disamping itu, para pejabat birokrasi seringkali tidak menempatkan efesiensi pelayanan, misalnya melalui penghematan biaya pelayanan, sebagai isu penting karena mereka tidak memiliki dorongan dan insentif untuk menekan biaya layanan. Bahkan, insentif, seperti keuntungan pribadi, kadang-kadang justru diperoleh ketika biaya pelayanan itu menjadi semakin tinggi. Adalah tidak mengherankan kalau kemudian banyak pihak mengatakan bahwa para pejabat birokrasi itu adalah budget-maximizing animals (Dunleavy, 2001: 97). Artinya, dengan anggaran yang besar mereka dapat memaksimalkan slack (kekendoran) yang dapat dipergunakan untuk kepentingan birokrasi dan dirinya.

Sumber kelemahan birokrasi pemerintah lainnya dalam melakukan pelayanan publik selama ini adalah kecenderungannya untuk menghasilkan ketimpangan kekuasaan dan memberi privilages (hak atau layanan istimewa) kepada kelompok tertentu pada masyarakat. Banyak kasus menunjukkan bias kebijakan pelayanan birokrasi yang memihak pada elit politik dan ekonomi, dan merugikan kepentingan masyarakat banyak. Praktik kolusi seringkali terjadi antara birokrasi dengan pengusaha dan pemegang kekuasaan politik. Pemberian kewenangan monopoli dan fasilitas-fasilitas khusus lainnya kepada kelompok pengusaha tertentu dalam pelayanan bisa menjadi contoh dari privilages itu. 
Pada umumnya, pelayanan publik oleh birokrasi pemerintah di lingkungan lembaga Kantor Kelurahan juga masih memiliki kelemahan sebagaimana gambaran yang diuraikan di atas. Kelemahan tersebut tentunya harus diminimalisir agar pelayanan yang diberikan kepada masyarakat benar-benar sesuai dengan perspektif atau harapan dari UU No. 32 Tahun 2004 tentang Pemerintahan Daerah, yang didalam pasal 127 ayat (3) antara lain Lurah mempunyai tugas pokok memberikan pelayanan masyarakat yang sebaik-baiknya. Pelayanan yang dimaksud antara lain pelayanan KTP, Kartu Keluarga (KK), perijinan tertentu, dan sebagainya.

Selanjutnya, menyangkut bentuk-bentuk pelaksanaan pelayanan pemerintah. Secara normatif yang lainnya yang dapat dijadikan pembanding acuan teoretik adalah pola-pola (bentuk) implementasi pelayanan publik berdasarkan Kep. Menpan No. 63 Tahun 2003, yaitu: pola fungsional (pola pelayanan publik diberikan oleh penyelenggara pelayanan sesuai dengan tugas, fungsi, dan kewenangannya); pola terpusat (pola pelayanan publik diberikan secara tunggal oleh penyelenggara pelayanan berdasarkan pelimpahan wewenang dari penyelenggara pelayanan terkait lainnya yang bersangkutan); pola terpadu; dan pola gugus (tugas petugas pelayanan publik secara perorangan atau dalam bentuk gugus tugas ditempatkan pada instansi pemberi pelayanan dan lokasi pemberian pelayanan tertentu).

Pola terpadu terdiri dari: pola terpadu satu atap (diselenggarakan dalam satu tempat yang meliputi berbagai jenis pelayanan yang tidak mempunyai keterkaitan proses dan dilayani melalui beberapa pintu, dan terhadap jenis pelayanan yang sudah dekat dengan masyarajat tidak perlu disatuatapkan); serta pola terpadu satu pintu (diselenggarakan pada satu tempat yang meliputi berbagai jenis pelayanan yang memiliki keterkaitan proses dan dilayani melalui satu pintu).

Selain keempat pola (bentuk) di atas, instansi yang mengimplementasikan pelayanan publik dapat mengembangkan pola penyelenggaraan pelayanannya sendiri dalam rangka upaya menemukan dan menciptakan inovasi peningkatan pelayanan publik.

\section{Orientasi dan Manajemen Pelayanan Pemerintah}

Dewasa ini, orientasi pelayanan publik/pemerintah mencoba menggabungkan ide-ide manajemen sektor publik dan privat. Penggabungan tersebut dilakukan dengan memperjelas tujuan dan menjamin bahwa pengguna lebih diperhatikan dalam memberikan pelayanan (Osborne dan Perlie, 2007: 102).

Orientasi pelayanan publik yang demikian di atas sangat mengutamakan kualitas pelayanan. Pelayanan yang berkualitas diasumsikan dengan mengenali misi birokrasi. Misi merupakan penuntun langkah dan gerak birokrasi ; misi dan visi merupakan motor penggerak birokrasi. Budaya dikembangkan secara lebih beraneka ragam, secara berdayaguna dan berhasilguna, ekonomis, serta dipertanggung jawabkan untuk keberhasilannya. Di samping itu, strukturnya ramping, luwes, cepat bergerak, dan sangat desentralistis. Sementara kepemimpinan dilakukan dengan demokratis dan transformasional di semua tingkat pimpinan, mulai dari pimpinan tingkat atas sampai ke pimpinan tingkat bawah.

Dalam konteks di atas, maka birokrasi dituntut lebih kreatif dalam melayani masyarakat, viable, dan inovatif. Ajang untuk itu sangat tersedia karena ukuran berhasil dan tidaknya seseorang dalam melayani masyarakat dikembalikan ke visi dan misi organisasi, bukan pada ukuran-ukuran stndar baku yang kaku. Sistem rekrutmen dan pengembangan karier dilakukan secara terbuka dan melibatkan banyak orang dalam melayani masyarakat.

Disamping itu, Osborne dan Perlie (2007: 155) menambahkan bahwa dalam hal kaitannya dengan pelayanan publik (public service), birokrasi yang baik adalah birokrasi yang memiliki tujuan yang jelas, sistem insetifnya didasarkan pada prestasi kerja, mempersilahkan konsumen terlibat dan memegang kendali pada keluaran birokrasi atau ada ruang bagi pengguna jasa birokrasi untuk terlibat, mengalihkan kendali pengambilan keputusan pada pegawai di tingkat bawah, terutama ketika mereka berhadapan dengan situasi sulit yang membutuhkan keputusan segera untuk melayani masyakakat, atau ada ruang gerak bagi pegawai yang melayani masyarakat di tingkat bawah untuk berinovasi, serta harus ada budaya wirausaha di intern birokrasi.

Orientasi pelayanan publik sebagaimana dikemukakan oleh Osborne di atas paling tidak bertujuan agar: orientasi pelayanan publik terhadap pengguna jasa; pelibatan pengguna jasa pada keluaran birokrasi; serta pengukuran terhadap hasil kerja, layanan, prestasi, dan penampilan dalam melakukan pelayanan masyarakat. Usaha mengejar ketiga tujuan itu, pada akhirnya akan bermuara pada peningkatan kualitas pelayanan publik, termasuk peningkatan kepuasan masyarakat atas pelayanan yang diberikan oleh pemerintah.

Selanjunya berkaitan dengan manajemen pelayanan pemerintah, sejalan dengan besarnya tuntutan akan good governance (kepemerintahan yang baik), maka tuntutan akan pelayanan publik yang berkualitas juga menjadi semakin besar. Pemerintah merespon tuntutan ini dengan menetapkan tahun 2004 sebagai tahun peningkatan pelayanan publik. Pemerintah juga telah mengeluarkan berbagai kebijakan dalam rangka peningkatan pelayanan, seperti kebijakan pelayanan prima, dan Standar Pelayanan Minimal (SPM). Akan tetapi, perbaikan kualitas masih belum berjalan sebagaimana yang diharapkan oleh Instruksi Presiden No. 1 Tahun 1995 tentang Perbaikan dan 
Peningkatan Mutu Pelayanan Aparatur Pemerintah Kepada Masyarakat.

Peningkatan kualitas pelayanan merupakan salah satu isu yang sangat krusial dalam studi manajemen, baik dalam lingkup manajemen sektor publik maupun manajemen sektor privat. Hal ini terjadi karena di satu sisi tuntutan masyarakat terhadap perbaikan kualitas pelayanan dari tahun ke tahun menjadi semakin besar. Sementara itu, praktik penyelenggaraan pelayanan kurang mengalami perbaikan yang cukup berarti atau signifikan.

Dalam hubungannya dengan teori "exit" (pengguna jasa diberi kesempatan untuk memilih penyedia jasa yang disukainya, karena ada beberapa penyedia jasa yang memberikan pelayanan publik yang sejenis yang saling bersaing dalam pelaksanaan pelayanan publik yang berkualitas) dan teori "voice" (pengguna jasa pelayanan harus diberi kesempatan untuk mengungkapkan ekspresi ketidak puasannya atas pelayanan yang di terimanya), manajemen pelayanan yang baik hanya akan dapat diwujudkan apabila penguatan posisi tawar pengguna jasa pelayanan mendapatkan prioritas utama (Imai, 2002: 44).

Dengan demikian, pengguna jasa diletakkan di pusat dan mendapatkan dukungan dari: sistem pelayanan yang mengutamakan kepentingan masyarakat, khususnya pengguna jasa; kultur pelayanan dalam organisasi penyelenggara pelayanan; serta sumberdaya manusia yang berorientasi pada kepentingan pengguna jasa atau masyarakat yang dilayani (Ratminto dan Winasih, 2005: 189).

Jadi, penguatan posisi tawar yang dimaksudkan untuk menyeimbangkan hubungan antara penyelenggara pelayanan dan pengguna jasa pelayanan ini juga harus diimbangi dengan berfungsinya mekanisme "voice" yang dapat diperankan oleh media, Lembaga Sosial Masyarakat (LSM), organisasi profesi, ombudsmen (semacam lembaga pengawas independen yang menilai dan mengawasi pelaksanaan pelayanan publik), dan lainnya.

Adapun model manajemen pelayanan publik yang dikaitkan dengan hal di atas dapat dilihat pada Gambar 1.

\section{Standar dan Mutu Pelayanan Pemerintahan}

Setiap penyelenggaraan pelayanan publik harus memiliki standar pelayanan dan dipublikasikan sebagai jaminan adanya kepastian bagi penerima pelayanan. Standar pelayanan merupakan ukuran yang dibakukan dalam pelaksanaan pelayanan publik yang wajib diatasi oleh pemberi dan atau penerima pelayanan.

Sebagai pembanding acuan teoretis, secara normatif Keputusan Menpan No. 63 Tahun 2003 menyebutkan standar pelayanan publik, yaitu sekurang-kurangnya meliputi: prosedur pelayanan (prosedur pelayanan yang dibakukan bagi penerima dan pemberi pelayanan, termasuk pengaduan); waktu penyelesaian (ditetapkan sejak saat pengajuan permohonan sampai dengan penyelesaian pelayanan, termasuk pengaduan); biaya pelayanan (termasuk rinciannya yang ditetapkan dalam proses pemberian pelayanan); produk pelayanan (hasil pelayanan yang akan diterima sesuai dengan ketentuan yang telah ditetapkan); sarana dan prasarana (penyediaan sarana dan prasarana pelayanan yang memadai oleh penyelenggara pelayanan publik; serta kompetensi petugas pemberi pelayanan publik (harus ditetapkan dengan tepat berdasarkan pengetahuan, keahlian, keterampilan, sikap, dan perilaku yang dibutuhkan).

Selanjutnya berkaitan dengan mutu pelayanan pemerintah, Imai (2002: 38) memilih untuk tidak mendefinisikan mutu atau kualitas, melainkan mengatakan bahwa kualitas menunjukkan pada sesuatu yang dapat diperbaiki, baik menyangkut produk dan pelayanan, cara kerja pegawai, cara mengelola mesin, cara orang berjalan mengikuti sistem dan aturan.

Berbeda dengan di Barat yang lebih menekankan pada peningkatan kualitas teknik pelayanan. Dalam rumusan ini terlihat bahwa di Jepang misalnya, penekanannya adalah pada peningkatan kualitas manusia dan cara kerjanya melayani masyarakat. Konsepnya adalah pada awal tahun 1970-an dikembangkan menjadi Total Quality Control (TQC) yang melibatkan seluruh pekerja dan pimpinan di semua tingkat di perusahaan-perusahaan Jepang, dan termasuk diikuti akhir-akhir ini oleh pegawai di lingkungan pemerintahan.

Menurut Loffler (2006: 179), prinsip dasar kualitas dari $T Q C$ di atas antara lain adalah: tuntutan pegawai akan berkualitas yang lebih baik dalam pekerjaan mereka melayani masyarakat; meningkatkan standar kualitas pelayanan; kepuasaan konsumen atau masyarakat adalah tujuan utama dari pelayanan; perbaikan kualitas pelayanan harus dilakukan secara ajeg (beraturan); serta kualitas pelayanan dapat diukur oleh konsumen aatau masyarakat.

Keberhasilan pelaksanaan prinsip-prinsip kualitas di atas harus didukung antara lain: mendefinisikan ulang produk-produk layanan yang dihasilkan oleh instansi pemerintah; melakukan kritik terhadap proses pelayanan untuk menemukan prosedur dan persyaratan layanan yang tidak diperlukan lagi; menyusun prosedur dan persyaratan layanan yang lebih sederhana; melakukan pelatihan pelayanan terhadap pegawai tentang prosedur baru; menerapkan prosedur baru pelayanan, dengan selalu meminta umpan balik atau kritik dari konsumen atau masyarakat yang dilayani (Samodra dan Yuyun, 2008: 186). 


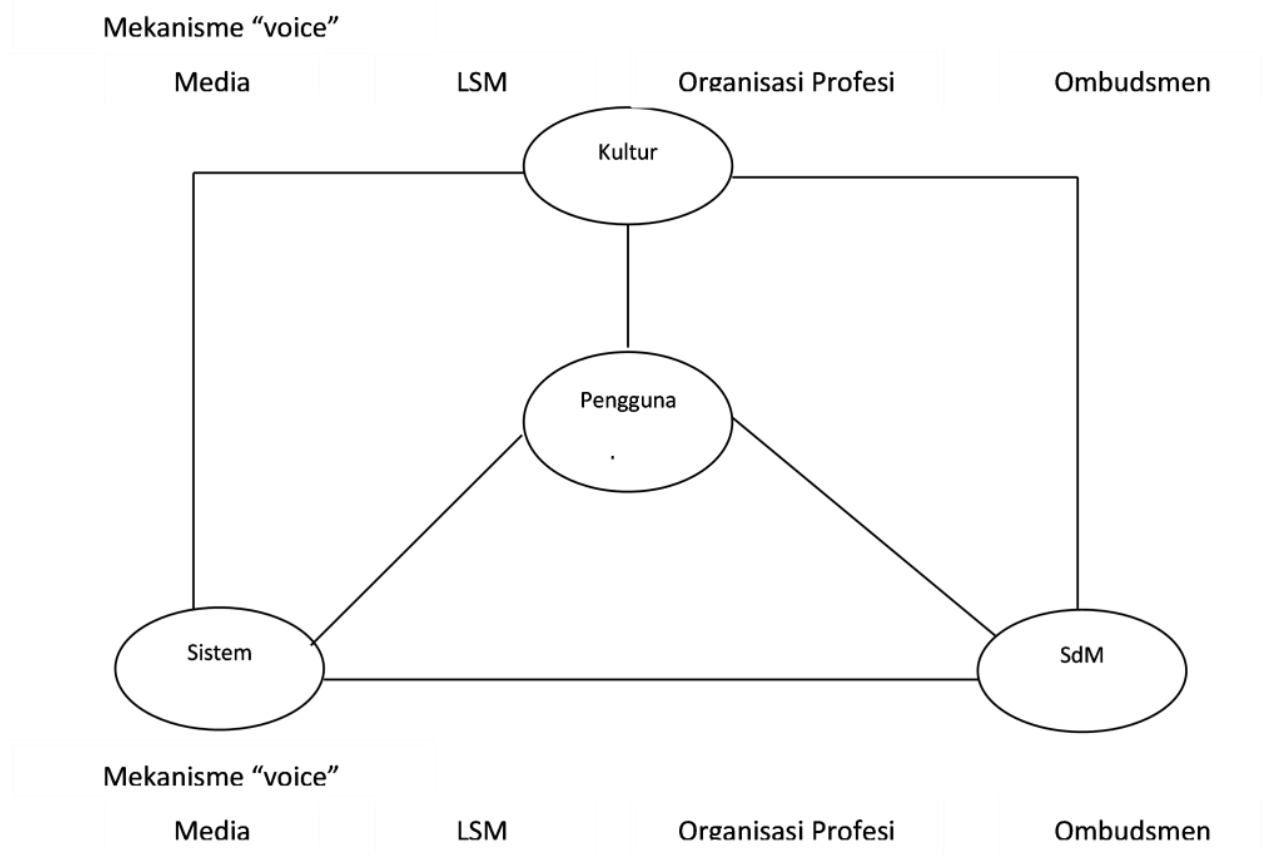

Gambar 1. Model Manajemen Pelayanan Pemerintah

Kemudian, secara umum ukuran tingkat kualitas pelayanan (berlaku pula untuk pelayanan publik) antara lain dikemukakan oleh Zeithaml, Parasumaran, dan Berry (2000: 204), adalah: (1) keandalan, yaitu pekerjaan cepat dan pelayanan tidak pilih kasih (menyangkut sejauhmana informasi pelayanan yang diberikan kepada masyarakarat tepat dan dapat dipertanggung jawabkan. Selain itu, dikaitkan pula apakah masyarakat segera mendapatkan perbaikan pelayanan apabila terjadi kesalahan dalam melayani); (2) keresponsifitas, yaitu pelayanan yang menyenangkan dan ketangkasan dalam bekerja (menyangkut bagaimana respon penyedia layanan jika ada masyarakat yang kompalin, serta apakah penyedia layanan segera memberi penyelesaian secara tepat); (3) pengetahuan dan keterampilan, yaitu pegawai mampu bekerja dan pegawai mampu melaksanakan tugas pelayanan (menyangkut kesesuaian antara kemampuan petugas dengan fungsi atau tugas pelayanan, apakah penyedia layanan cukup tanggap untuk melayani masyakat, serta apakah organisasi mengadakan pelatihan untuk meningkatkan kemampuan aparat pelayan sesuai dengan perkembangan atau perubahan tugas pelayanan); (4) perilaku, yaitu sopan kepada masyarakat, melayani dengan baik, dan pelayanan pribadi kepada masyarakat (menyangkut bagaimana sikap petugas dalam memberikan pelayanan kepada masyarakat, serta apakah petugas cukup ramah dan sopan); (5) kejujuran, yaitu kejujuran dalam bekerja dan masyarakat mempercayai pegawai dalam melakukan pelayanan (menyangkut reputasi kantor pelayanan, apakah biaya yang dibayarkan oleh masyarakat sesuai dengan keluaran atau jasa layanan yang diperoleh, serta apakah petugas selalu ada selama jam kerja); (6) keamanan, yaitu jaminan pelayanan dan memberikan jaminan hukum (menyangkut apakah ada jaminan keamanan atau keselamatan terhadap masyarakat dalam mekanisme pelayanan); (7) kemudahan hubungan, yaitu memberi pelayanan pengaduan dan pendekatan menyeluruh (menyangkut bagaimana masyarakat mendapatkan infromasi pelayanan, apakah masyarakat murah dan mudah menghubungi petugas untuk mendapatkan pelayanan, apakah lokasi kantor pelayanan mudah dijangkau oleh semua masyarakat, apakah prosedur yang diterapkan sederhana, serta apakah informasi pelayanan untuk manyarakat mudah didapat dan jelas); (8) komunikasi, yaitu pandai memikat masyarakat, pandai berpikir, dan rajin memberikan berita yang aktual yang berkaitan dengan pelayanan (menyangkut bagaimana petugas menjelaskan prosedur atau mekanisme untuk mendapatkan pelayanan, apakah masyarakat segera bisa mendapatkan respon jika terjadi kesalahan dalam pelayanan, semua pengaduan atau keluhan akan dijawab dengan segera dan jika perlu keluhan atau pengaduan diberi follow-up secara detail, serta ketersediaan umpan balik lewat radio atau media lainnya) (Sedarmayanti, 2000: 80-81); dan (9) mengerti kebutuhan masyarakat), yaitu memenuhi kebutuhan konsumen dan memberikan pelayanan yang memuaskan (menyangkut apakah penyedia layanan tanggap terhadap kepentingan dan kebutuhan riil masyarakat yang dilayani).

Pemerintah harus melakukan perbaikan mutu atau kualitas pelayanan publik. Seluruh masyarakat mempunyai hak yang sama dari pemerintah atas jaminan (assurance) sosial ekonomi, jaminan keamanan yang memadai dan penegakan hukum yang berpijak pada keadilan sebagai konsekuensi langsung atas pembayaran pajak yang telah mereka 
penuhi. Pemerintah diharapkan bisa mendorong organisasi-organisasi penyedia layanan publik, seperti lembaga pendidikan, kesehatan, transportasi, listrik, telepon, PDAM dan sebagainya untuk memenuhi kebutuhan masyarakat secara layak. Pelayanan publik sebagaimana SK Men-PAN Nomor $81 / 1993$ adalah segala bentuk kegiatan pelayanan publik (umum) yang dilaksanakan oleh instansi pemerintah dan BUMN atau BUMD dalam bentuk barang dan atau jasa baik dalam upaya pemenuhan kebutuhan masyarakat maupun pelaksanaan ketentuan peraturan perundang-undangan. Kualitas pelayanan publik ini harus selalu dimonitor dari waktu ke waktu agar tercipta perbaikan secara terus menerus. Di satu sisi, informasi tentang apa yang sebenarnya dibutuhkan masyarakat harus selalu digali agar mengurangi gap (kesenjangan) antara harapan masyarakat dengan praktik penyelenggaraan layanan publik yang ada. Masyarakat harus diberi kesempatan untuk berpartisipasi dalam menentukan prioritas kebutuhannya dan mengembangkan kapabilitasnya sehingga mempunyai tingkat produktivitas yang tinggi.

Kebijakan dan regulasi yang ditetapkan pemerintah pada satu bidang tertentu bisa berimbas pada bidang yang lain. Pada saat pemerintah menaikkan harga BBM maka akan selalu diikuti kenaikan harga pada bidang lain misalnya jasa transportasi. Demikian juga jika tarip listrik dinaikkan maka secara tidak langsung juga mempengaruhi tarip di bidang lainnya misalnya di bidang pendidikan dan kesehatan, yang harus ditanggung masyarakat. Bahkan akibat struktur biaya yang berubah ini, kenaikan harga bahan-bahan kebutuhan pokok pun tidak bisa dihindarkan. Jika memang kenaikan harga-harga tersebut sifatnya tidak bisa dihindari (unavoidable) maka semestinya diimbangi pula dengan peningkatan manfaat langsung atas layanan organisasi publik. Peningkatan kualitas pelayanan publik dengan mengoptimalkan output bagi kemanfaatan masyarakat seharusnya juga tidak bisa dihindari guna membantu meringankan beban masyarakat.

Pemerintah mempunyai peran besar dalam pembuatan program pelayanan dan kebijakan publik. Berbagai regulasi dan peraturan yang menyangkut organisasi layanan publik sudah barang tentu mesti dirumuskan dengan mempertimbangkan kebutuhan publik. Tanggung jawab pemerintah tidak sekedar membuat dan menjalankan program yang bernilai ekonomi tetapi yang lebih penting justru identifikasi apakah program dan kebijakan tersebut sudah sesuai dengan keinginan publik dan tidak malah membatasi ruang gerak masyarakat untuk bisa berkreasi secara produktif. Tingkat kehidupan masyarakat secara individual diharapkan bisa bertambah baik dan maju atas kebijakan pemerintah yang ditetapkan.

Beberapa negara telah berusaha memperbaiki kualitas pelayanan publik ini dalam rangka melindungi dan memenuhi kebutuhan masyarakat.
Pemerintahan di Inggris tahun 1998 berupaya merumuskan Public Service Agreements sebagai bentuk kesepakatan baru peningkatan pelayanan publik. Kesepakatan pelayanan publik ini dimaksudkan untuk menghimpun berbagai perbaikan khusus dalam pelayanan sebagaimana diharapkan masyarakat. Sementara di Australia, upaya memperbaiki kualitas pelayanan publik ini dilakukan dengan monitoring kinerja semua organisasi penyedia layanan publik secara berkelanjutan oleh Komisi Industri (The Industry Commission) yang ditugaskan khusus Pemerintah. Jadi, pemerintah mempunyai peranan cukup besar untuk untuk mewujudkan tercapainya perbaikan kualitas layanan publik dengan efektif.

Upaya memperbaiki kinerja organisasi layanan publik ini dilakukan secara terus menerus sehingga bisa dilihat kemanfaatannya bagi masyarakat. Dengan demikian, para klien dan pengguna jasa organisasi publik tersebut dapat menerima layanan sesuai dengan kebutuhannya, lebih relevan dan efektif. Selain itu, para wajib pajak menerima imbal balik yang sepadan dan efektif oleh karena mereka dapat menikmati pelayanan dari lembaga layanan publik dengan memuaskan.

Upaya peningkatan kualitas pelayanan publik dapat dilakukan dengan cara memperbaiki manajemen kualitas jasa (service quality management), yakni upaya meminimasi kesenjangan (gap) antara tingkat layanan yang disediakan organisasi dengan harapan dan keinginan customer (masyarakat pengguna). Dalam rangka memperbaiki kualitas layanan ini, manajemen harus mampu menerapkan teknik-teknik manajemen yang berorientasi pada kebutuhan customer. Pengukuran kinerja secara periodik sangat perlu dilakukan untuk mengidentifikasi tingkat kesenjangan yang terjadi. Kinerja merupakan konsep yang multi dimensional dan banyak dipengaruhi berbagai macam faktor. Ukuran kinerja yang layak bagi organisasi layanan publik ini tidak sekedar bersifat finansial (input). Kinerja organisasi layanan publik harus diukur dari outcome-nya karena outcome (hasil) inilah variabel kinerja yang paling mewakili derivasi (penurunan) dari misi organisasi sampai pada aktivitas operasional. Outcome dapat digunakan untuk menilai aspek finansial dan non finansial sekaligus. Tujuan strategis organisasi, kepuasan pelanggan dan kontribusi ekonomi secara bersama-sama dapat diukur ketercapainnya dengan mengidentifikasi outcome-nya. Keberhasilan sebuah rumah sakit bukan dilihat dari fasilitasnya (output) tetapi dari kemanfaatan langsung atas keberadaan fasilitas tersebut bagi masyarakat (outcome). Keberhasilan pembangunan gedung sekolah dasar bukan dilihat dari banyaknya bangunan SD (yang dikenal dengan SD Inpres) di berbagai wilayah pedesann (output) sebagaimana ditetapkan dalam program pembangunan, namun dari seberapa besar nilai 
strategis gedung tersebut bagi pemenuhan kebutuhan masyarakat.

Selanjutnya, monitoring kinerja perlu dilakukan sebagai alat untuk mengevaluasi apakah pelayanan publik dan program-program organisasi penyedia layanan publik ini sudah sesuai dengan apa yang dibutuhkan masyarakat. Monitoring kinerja dapat juga digunakan untuk mengidentifikasi apakah tingkat kualitas pelayanan publik sudah lebih baik daripada sebelumnya. Dengan dilakukan monitoring kinerja secara berkelanjutan, sebenarnya akan membantu meningkatkan efisiensi dan efektivitas organisasi layanan publik itu sendiri. Beberapa langkah penting monitoring kinerja organisasi layanan publik antara lain: (1) Mengembangkan indikator kinerja yang menggambarkan pencapaian tujuan organisasi sehingga ada kejelasan tentang apa sebenarnya yang hendak dicapai organisasi dan bagaimana cara mengukur pencapaian tujuan organisasi tersebut, (2) Memaparkan hasil pencapaian terhadap tujuan dan program berdasarkan indikator kinerja di atas, dan (3) Berdasarkan paparan hasil penilaian pencapaian tujuan dan program di atas dapat diindentifikasi apakah organisasi sudah melakukan kegiatan secara efektif dan efisien sebagai dasar untuk perbaikan kualitas pelayanan kepada masyarakat umum.

Pertanyaan mendasar dalam proses monitoring ini adalah bagaimana sumberdaya digunakan dan apakah tindakan yang diperlukan untuk menjamin tercapainya pengelolaan sumberdaya secara ekonomi, efisien dan efektif sudah dilakukan? Jika organisasi layanan publik ini adalah rumah sakit, maka monitoring kinerja berarti menjawab pertanyaan tentang apakah rumah sakit tersebut sudah mengelola sumberdaya secara optimal dan menyediakan layanan terbaik untuk kepuasan para pengguna atau masyarakat. Adanya perbaikan kualitas pelayanan dapat diidentifikasi dari menurunnya tingkat komplain dari pasien atau pengguna, kepuasan pasien, meningkatnya jumlah pasien dan meningkatnya kepercayaan masyarakat umum. Organisasi layanan publik seperti rumah sakit ini harus berorientasi pada outcome dan bukan sekedar input dan output. Jadi, indikator kinerja atas kualitas pelayanan sebuah rumah sakit bukan sekedar jumlah dokter per pasien, jumlah kamar untuk setiap kelas atau jumlah pengeluaran yang tidak melebihi anggaran tetapi yang lebih penting adalah tingkat kepuasan yang dirasakan oleh para pengguna jasa rumah sakit tersebut karena harapan dan kebutuhannya dapat tercapai.

Masih sering terjadi hingga saat ini organisasi layanan publik yang tidak berorientasi pada masyarakat pengguna (apa yang dibutuhkan oleh pengguna). Artinya, pengguna (user/customer) bukan menjadi perhatian utama, dengan pertimbangan bahwa mereka pasti membutuhkan jasa atau layanan publik ini. Tanpa harus dengan pelayanan yang baik pun masyarakat pasti akan datang. Pola pikir (mind set) seperti ini sudah sepantasnya diubah. Kembali lagi kepada pemerintah, terutama pemerintah daerah, untuk berperan dan mengambil bagian sebagian otorisasi organisasi layanan publik agar memperbaiki kualitas layanan dengan penetapan regulasi dan kebijakan yang lebih aspiratif terhadap kebutuhan publik. Kebijakan otonomi daerah seharusnya dapat digunakan wahana perbaikan kualitas layanan publik. Dengan pemerintahan yang terdesentralisasi tersebut pemerintah daerah menjadi lebih dekat dengan masyarakatnya dan lebih memahami aspirasi serta kebutuhannya. Bahkan kualitas layanan publik oleh Pemda sendiri juga harus ditingkatkan. Hubungan Pemda dengan masyarakat bukan berpola patron-client, tetapi menempatkan masyarakat sebagai customer yang harus dilayani apa yang menjadi kebutuhannya dengan baik. Pentingnya memperhatikan keinginan masyarakat ini semoga dapat menjadi renungan organisasi layanan publik seperti Pemda, PLN, PT Telkom, PDAM, lembaga pendidikan, kesehatan dan sebagainya agar tetap menjadi mitra yang baik bagi masyarakat dalam meningkatkan kesejahteran dan produktivitasnya.

\section{Cara Pengukuran Tingkat Kepuasan Masyarakat Terhadap Pelaksanaan Kebijaka Pelayanan Pemerintah}

Ratminto dan Winarsih (2005: 69-70) mengemukakan bahwa ada 14 (empat belas) unsur yang "relevan, valid, dan reliabel" sebagai unsur minimal yang harus ada untuk dasar pengukuran (parameter atau indikator) indeks kepuasaan masyarakat atas pelayanan publik oleh pemerintah, yaitu:

(1) Prosedur pelayanan, yaitu kemudahan tahapan pelayanan yang diberikan kepada masyarakat dilihat dari sisi kesederhanaan alur pelayanan.

(2) Persyaratan pelayanan, yaitu persyaratan teknis dan administratif yang diperlukan untuk mendapatkan pelayanan sesuai dengan jenis pelayanannya.

(3) Kejelasan petugas pelayanan, keberadaan dan kepastian petugas yang memberikan pelayanan (nama, jabatan, serta kewenangan dan tanggung jawabnya).

(4) Kedisplinan petugas pelayanan, yaitu kesungguhan petugas dalam memberikan pelayanan, terutama terhadap konsistensi waktu kerja sesuai ketentuan yang berlaku.

(5) Tanggung jawab petugas pelayanan, kejelasan wewenang dan tanggung jawab petugas dalam penyelenggaraan dan penyelesaian pelayanan.

(6) Kemampuan petugas pelayanan, yaitu tingkat keahlian dan keterampilan yang dimiliki petugas dalam memberikan atau menyelesaikan pelayanan kepada masyarakat.

(7) Kecepatan pelayanan, yaitu target waktu pelayanan dapat diselesaikan dalam waktu yang telah ditentukan oleh unit penyelenggara 
pelayanan.

(8) Keadilan mendapatkan pelayanan, yaitu pelaksanaan pelayanan dengan tidak membedakan golongan atau status masyarakat yang dilayani.

(9) Kesopanan dan keramahan petugas, yaitu sikap dan perilaku petugas dalam memberikan pelayanan kepada masyarakat secara sopan dan ramah serta saling menghargai dan menghormati.

(10) Kewajaran biaya pelayanan, yaityu keterjangkauan masyarakat terhadap besarnya biaya yang ditetapkan oleh unit pelayanan.

(11) Kepastian biaya pelayanan, yaitu kesesuaian antara biaya yang dibayarkan dengan biaya yang telah ditetapkan.

(12) Kepastian jadwal pelayanan, yaitu pelaksanaan waktu pelayanan, sesuai dengan ketentuan yang telah ditetapkan.

(13) Kenyamanan lingkungan, yaitu kondisi sarana dan prasarana pelayanan yang bersih, rapi, dan teratur sehingga dapat memberikan rasa nyaman kepada penerima pelayanan.

(14) Keamanan pelayanan, yaitu terjaminnya tingkat keamanan lingkungan unit penyelenggara pelayanan ataupun sarana yang digunakan, sehingga masyarakat merasa tenang untuk mendapatkan pelayanan terhadap resiko-resiko yang diakibatkan dari pelaksanaan pelayanan.

Unsur-unsur pengukuran di atas dapat dijabarkan secara aplikatif dalam sebuah riset dalam bentuk instrumen kuesioner guna dapat mengetahui puas tidaknya masyarakat atas pelayanan yang diberikan oleh aparatur pemerintah, seperti dicontohkan pada Tabel 1.

Jadi, paling tidak ada 14 unsur yang dapat menentukan puas tidaknya masyarakat atas pelayanan yang diberikan oleh aparatur pemerintah, dan juga dapat diposisikan sebagai faktor-faktor yang menentukan atau mempengaruhi puas tidaknya masyarakat. Unsur-unsur tersebut dapat dijabarkan secara aplikatif menjadi 28 item instrumen riset. Apa yang dicontohkan ini lebih lengkap unsur-unsurnya dari apa yang dikemukakan dalam Permenpan dan RB No. 16 Tahun 2014 tentang Pedoman Survei Kepuasan Masyarakat Terhadap Penyelenggaraan Pelayanan Publik. Penjelasan tersebut dapat dilihat pada Gambar 2.

Pelaksanaan survei kepuasan masyarakat terhadap penyelenggaraan pelayanan publik dapat dilaksanakan melalui tahapan perencanaan, persiapan, pelaksanaan, pengolahan dan penyajian hasil survei, yang mencakup langkah-langkah sebagai berikut: Menyusun instrumen survei (seperti instrumen yang dicontohkan di atas); Menentukan besaran dan teknik penarikan sampel; Menentukan responden; Melaksanakan survei; Mengolah hasil survei; dan Menyajikan dan melaporkan hasil.Tahapan penyelenggaraan survei kepuasan masyarakat terhadap penyelenggaraan pelayanan publik ini perlu didasarkan pada metode dan teknik yang dapat dipertanggungjawabkan.

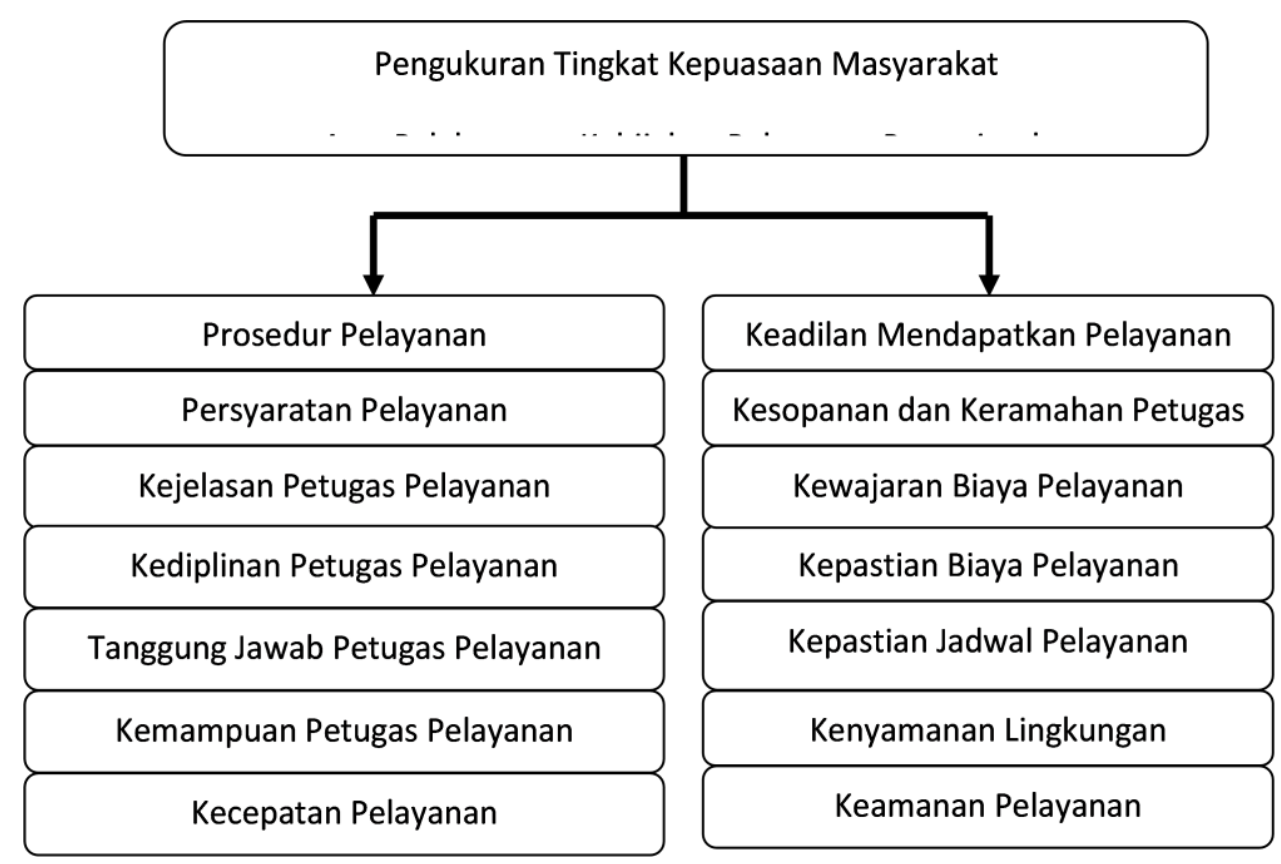

Gambar 2. Skema Pengukuran Tingkat Kepuasan Masyarakat Atas Pelaksanaan Kebijakan Pelayanan Pemerintah 


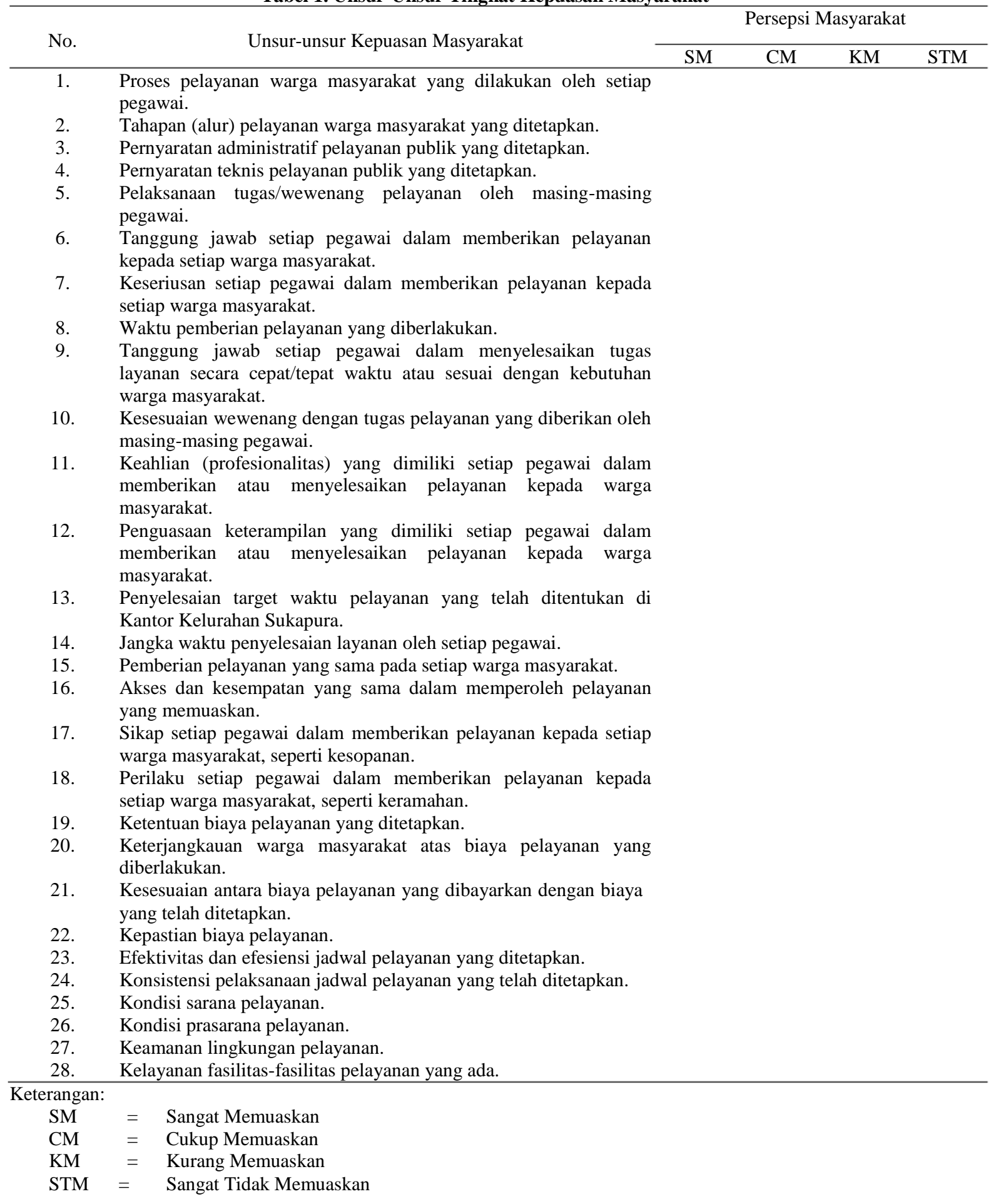

Untuk melakukan survei dapat menggunakan teknik survei, antara lain: Kuesioner dengan wawancara tatap muka; Kuesioner melalui pengisian sendiri, termasuk yang dikirimkan melalui surat; Kuesioner elektronik (internet/e-survey); Diskusi kelompok terfokus; dan Wawancara tidak berstruktur melalui wawancara mendalam. Hasil survei kepuasan masyarakat dimaksudkan untuk: Mengetahui kelemahan atau kekuatan dari masingmasing unit penyelenggara pelayanan publik; Mengukur secara berkala penyelenggaraan pelayanan yang telah dilaksanakan oleh unit pelayanan publik; Sebagai bahan penetapan kebijakan yang perlu diambil dan langkah perbaikan pelayanan; serta Sebagai umpan balik dalam memperbaiki layanan. Masyarakat harus terlibat secara aktif mengawasi pelaksanaan penyelenggaraan pelayanan publik 


\section{KESIMPULAN}

Sasaran pengukuran kepuasan masyarakat atas pelaksanaan kebijakan pelayanan pemerintah adalah harus mendorong partisipasi masyarakat sebagai pengguna layanan dalam menilai kinerja penyelenggara pelayanan, mendorong penyelenggara pelayanan untuk meningkatkan kualitas pelayanan, serta mendorong penyelenggara pelayanan menjadi lebih inovatif dalam menyelenggarakan pelayanan publik. Survei kepuasan masyarakat terhadap penyelenggaraan pelayanan publik perlu dilakukan secara berkelanjutan sebagai dasar peningkatan kualitas dan inovasi pelayanan publik serta kemungkinan replikasi inovasi pelayanan publik.

Apapun hasil dari survei kepuasan masyarakat atas pelaksanaan kebijakan pelayanan publik, pemerintah harus segera bisa mengubah paradigma para aparatur dari mau dilayani menjadi pelayan, karena fungsi utama dari pemerintahan adalah memberikan pelayanan. Fungsi pelayanan inilah yang sering dilupakan oleh para birokrat. Hal-hal yang harus dilakukan untuk memperbaiki pelayanan publik terutama memperbaiki sistem rekrutmen. Sistem rekrutmen sangat penting, karena inilah awal dari adanya aparatur pemerintahan. Seleksi aparatur pemerintahan harus diperketat lagi dan tesnya harus diperbaiki, sehingga mampu menghasilkan pegawai yang profesional. Upaya ini harus diikuti dengan pemberian sangsi yang tegas. Dalam proses pelayanan seringkali petugas tidak melakukan apa yang sudah diatur dalam aturan, sehingga masyarakat tidak mendapatkan kepuasan. Petugas yang sering melanggar harus diberikan sangsi yang tegas, kalau perlu dipecat. Dengan adanya sangsi yang tegas ini diharapkan para aparatur pemerintahan tidak berani melakukan tindakan yang melanggar aturan. Selain itu, mempermudah proses layanan. Umumnya proses layanan bisa dikatakan berbelit-belit sering mengundang untuk terjadinya pungli. Jadi dalam proses layanan harus disederhanakan, supaya masyarakat senang mengurus. Pemerintah juga harus melakukan pendidikan dan pelatihan secara berkala bagi aparatur pemerintahan, sehingga memiliki kapabilitas dan profesionalitas tinggi dalam melayani masyarakat. 


\section{Daftar Pustaka}

Agus Dwiyanto. 2006. Kemitraan Pemerintah-Swasta dan Relevansi Terhadap Reformasi Administrasi Negara. JKAP, Volume 1, No. 1 (Mei), hal. 9-20.

Ahmad Dalin, Teuku. 2002 "Persepsi Pimpinan Terhadap Kualitas Pelayanan Birokrasi: Studi Kasus Di DIY.” Skripsi. Yogyakarta: Fisip UGM.

Albrecht, K dan L.J. Bradford. 2000. Kegunaan Pelayanan: Bagaimana Mengidentifikasi dan Memenuhi Kebutuhan Konsumen, diterjemahkan oleh A. Wulandari. Jakarta: Gramedia.

Collins dan McLaughlin. 2006. Perubahan Manajemen dalam Organisasi, diterjemahkan oleh Miftah Thoha. Jakarta: LP3ES.

Daha, Khairid. 2000. Kinerja Organisasi Pelayanan Publik: Studi Kasus pada Kartu Pendaftaran Penduduk Kota Samarinda. Skripsi. Yogyakarta: Fisip UGM.

Dahlan Al Barry. 2000. Kamus Modern Bahasa Indonesia. Yogyakarta: Arkola.

Dunleavy, Patrick. 2001. "Demokrasi, Birokrasi, dan Pilihan Kebijakan Democracy", Penjelasan Ekonomi Dalam Ilmu Politik, diterjemahkan oleh Yuyun P. Yogyakarta: Gadjah Mada University Press.

Grosroos, C. 2000. Manajemen Pelayanan dan Pemasaran, diterjemahkan oleh Maskur. Jakarta: Rineka Cipa.

Handoko, T. Hani. 2005. Manajemen Personalia dan Sumberdaya Manusia. Yogyakarta: BPFE.

Imai, Masaaki. 2002. Kualitas Pekerja di Jepang, diterjemahkan oleh Agus Dwiyanto. Yogyakarta: Gadjah Mada University Press.

Ivancevich, Lorenzi, Skinner, dan Crosby. 2007. Manajemen Kualitas dan Kompetitif, diterjemahkan oleh Mohammad Musa. Jakarta: Fajar Agung.

Kedaulatan Rakyat. 20013. Layanan Akses Rumit dan Berbelit-belit. Tgl. 5 Juli 2013, hal. 5.

Kementerian Pendayagunaan Aparatur Negara. 1993. Keputusan Menpan No. 81 Tahun 1993 Tentang Pedoman Tatalaksana Pelayanan Umum.

Instruksi Presiden No. 1 Tahun 1995 Tentang Perbaikan dan Peningkatan Mutu Pelayanan Aparatur Pemerintah Kepada Masyarakat.

2004. Keputusan Menpan No.
KEP/25/M.PAN/2/2004 Tentang Pedoman
Umum Penyusunan Indeks Kepuasan Masyarakat Unit Pelayanan Instansi Pemerintah.

2004. Keputusan Menpan No. 63 Tahun 2004 Tentang Pedoman Penyelenggaraan Pelayanan.

2014. Permenpan dan RB No. 16 Tahun 2014 tentang Pedoman Survei Kepuasan Masyarakat Terhadap Penyelenggaraan Pelayanan Publik.

Loffler, Ekka. 2006. Modernisasi di Sektor Publik dalam Perspektif Perbandingan Internasional : Konsep dan Metode, diterjemahkan oleh Agus Dwiyanto. Yogyakarta: Gadjah Mada University Press.

Osborne, David dan P. Plastrik. 1007. Lima Strategi Reinventing Pemerintahan, diterjemahkan oleh Yuyun P. Yogyakarta: Gadjah Mada University Press.

Pamudji, S. 2004. Profesionalisme Aparatur Negara dalam Rangka Meningkatkan Pelayanan Publik, Widyapraja IIP Depdagri. No. 19 Tahun III, hal. 21-29.

Rasyid, Ryaas. 2009. Kebijakan Sumberdaya Aparatur yang Profesional Dalam Pelaksanaan Otonomi, Dewan, Edisi 08, hal. 4-7.

Ratminto. 2002. "Peningkatan Kualitas Pelayanan Publik Di Era Otonomi Daerah : Harapan Yang Belum Menjadi Nyata", dalam Jurnal ISIP Fak. ISIPOL UMY Yogyakarta, Vol. XI, No. 12, Perbuari 2003.

Ratminto dan Atik Septi Winarsih. 2005. Manajemen Pelayanan: Pengembangan Model Konseptual, Penerapan Citizen's Charter, dan Standar Pelayanan Minimal. Yogyakarta: Pustaka Pelajar.

Samodra Wibawa dan Yuyun Purbokusumo. 2008. "Peningkatan Kualitas Pelayanan Administrasi”, JKAP, Vol. 2, No. 2, hal. 3851.

Sedarmayanti. 2000. Sumberdaya Manusia dan Produktivitas Kerja. Bandung: Ilham Jaya.

Siagian, Sondang P. 2001. Patologi Birokrasi: Analisis, Identifikasi, dan Terapinya. Jakarta: Ghalia Indonesia.

Taliziduhu Ndhara. 2000. Ilmu Pemerintahan I. Jakarta: BKU IIP.

Thoha, Miftah. 2002. Beberapa Aspek Kebijakan Birokrasi. Yogyakarta: Media Widya Mandala.

Zeithaml, C., Parasuraman, dan Berry. 2000. Melaksanakan Kualitas Pelayanan, diterjemahkan oleh Mohammad Musa. Yogyakarta: Pustaka Pelajar. 
